\title{
Characterization of technological properties of sorghum and millet malt produced under control condition in Burkina Faso
}

\author{
Fidèle Wend-Bénédo TAPSOBA ${ }^{1 *}$, Serge SAMANDOULOUGOU ${ }^{1}$, \\ Hamidou COMPAORE ${ }^{1}$, Awa OUEDRAOGO ${ }^{2}$, Thomas Jean NDIG YENOUBA ${ }^{3}$, \\ Elie Wilfried Wendnongma BIEOGO ${ }^{4}$, Mamoudou Hama $\mathrm{DICKO}^{2}$ and \\ Hagrétou SAWADOGO-LINGANI ${ }^{1}$
}

${ }^{1}$ Département Technologie Alimentaire (DTA), Institut de Recherche en Sciences Appliquées et Technologies (IRSAT), Centre National de la Recherche Scientifique et Technologique (CNRST), 03 BP 7047 Ouagadougou 03, Burkina Faso.

${ }^{2}$ Laboratoire de Biochimie, Biotechnologie, Technologie Alimentaire et Nutrition (LABIOTAN), Département de Biochimie-Microbiologie (DBM), Université Joseph KI ZERBO, 03 BP 7021 Ouagadougou, Burkina-Faso. ${ }^{3}$ Université Catholique de l'Afrique de l'Ouest, Unité Universitaire à Bobo-Dioulasso (UCAO/UUB), 1052 Bobo-Dioulasso, Burkina Faso.

${ }^{4}$ Université Aube Nouvelle, 01 BP 234 Bobo-Dioulasso, Burkina Faso.

*Corresponding author; E-mail: tapfidelew@gmail.com; Tel.: (+226) 70582333

Received: 30-08-2021 $\quad$ Accepted: 23-11-2021 $\quad$ Published: 31-12-2021

\begin{abstract}
The aim of this study was to determine the technological properties of sorghum and millet malt produced under controlled conditions in Burkina Faso. Two types of steeping were carried out: steeping at normal pH (6.5) and at alkaline $\mathrm{pH}(8)$. Analyzes of the functional properties (diastatic power, alpha and beta amylase activity) of the samples of malts produced were carried out using Bernfeld modified methods. From the results, it appeared that the values of diastatic power, alpha and beta amylase and amylase activity increased significantly during the malting process $(\mathrm{p}<0.001)$. The highest values for the diastatic power of the malts were obtained with millet malt (378.86 UPD and 336.45 UPD respectively for normal steeping and alkaline steeping). As for the diastatic power of sorghum malts, it varied from 79.14 UPD to 266.17 UPD. A negative correlation emerged between the diastatic power and the $\mathrm{pH}(\mathrm{R}=-0.88)$, it also emerged that the diastatic power was much more correlated with the activity of alpha amylase $(R=0.99)$ than that of beta amylase $(R=0.6)$. Overall, the different types of malts exhibited satisfactory diastatic power and functional properties in accordance with standards for cereal malt production. These malts could therefore be used for the production of infant porridge in order to increase the energy density of porridge and also used in bread making to replace commercial enzymes often not appreciated by consumers. (C) 2021 International Formulae Group. All rights reserved.
\end{abstract}

Keywords: Millet, sorghum, malting, diastatic power, amylase. 


\section{INTRODUCTION}

Sorghum and millet constitute staple food grains of millions of people in arid and semi-arid areas in Africa, India and Asia (Cardoso et al., 2015; Li et al., 2017). These cereals are used directly or in malted and / or fermented form in the preparation of several traditional foods including porridge (especially for children), dough, alcoholic and nonalcoholic drinks (Oi and Kitabatake, 2003; Dicko et al., 2006). Sorghum has been malted for centuries and is used for the production of babies' food and traditional alcoholic and nonalcoholic beverages (Beta et al., 2014). Sorghum malt is used for the production of various foods such as tchoukoutou, Tchapalo and gowé and more recently, the use of sorghum malt for the production of infant porridge (Kayodé et al., 2011). It's give a high nutritional value of derived products (Kayodé et al., 2011). Also, finger millet can be incorporated as a source of dietary fiber both in the native and malted forms, in the preparation of various health foods without altering the dough characteristics or the quality of the final product (Rao and others 2004; Saleh et al., 2013). Therefore, germination of millet grains can be used as a technique or in combination with other processing treatments to prepare malt with high nutritional level that can be used for the preparation of several healthy and nutritional food products such as infant formula, complementary food products, and composite flours or food blends (Saleh et al., 2013). However, there is a need for the application of malting at an industrial scale using novel germinators enhanced by a control system of germination conditions to provide high-quality malt products that can be easy to master and consumed by larger populations to help in promoting millet and sorghum utilization (Saleh et al., 2013). Malting is one of the technological process used by several processers to transform sorghum and millet grains. It consists of three stages, namely: steeping, germination and drying. The optimum malting conditions for pearl millet seem to be essentially the same as for sorghum. In malting, germination is an important unit operation which needs greater attention. Germination of cereal may result in some biochemical modifications and produce malt with improved nutritional quality that can be used in various traditional recipes (Saleh et al., 2013). The malted flour was prepared from germinated, dried and milled fractions of sorghum, pearl millet and finger millet (Jaybhaye et al., 2011). This technique makes it possible to enrich cereals with hydrolytic enzymes such as betaamylase and alpha-amylase, in sugars, free amino acids and vitamins, thus improving the technological and nutritional quality of the derived products (Mbofung and Fombang, 2003 ; Kayodé et al., 2011). Malting also has the advantage of reducing anti-nutritional factors in cereal and inducing an increase in the bioavailability of minerals such as iron and zinc (Traoré et al., 2004; Kayodé, 2006, 2011). Therefore, malting generally improves the nutrient content and digestibility of foods and it could be an appropriate food-based strategy to derive iron and other minerals maximally from food (Saleh et al. 2013). The addition of malt to infant flours makes it possible to have porridges with high energy density (Elkhalil, 2001; Tou et al., 2003; Towo et al., 2003). Some studies reported that the use of flour from whole germinated wheat in controlled conditions improved loaf volume and crumb texture (Bellaio et al., 2014; Richter and Guo, 2014). These positive effects were assigned to the natural enzymes expressed during the germination process that might decrease or completely replace the quantity of commercial enzymes added to bread formulation.

The aim of this study was to determine the technological properties of sorghum and 
millet malt produced under controlled conditions in Burkina Faso.

\section{MATERIALS AND METHODS Vegetal material}

The vegetal material were sorghum and millet grains, which were purchased from national institute of environmental and agriculture research (INERA/Saria at Koudougou, Burkina Faso). Three types of variety (30 kg each other) were purchased, these include «IKMP5" for millet grains, "Framida" for red sorghum grains and "Kapèlga" for white sorghum grains.

\section{Malting procedure}

About $500 \mathrm{~g}$ of sorghum (white or red) on the one hand and millet on the other hand (three repetitions), were steeped in tap water after cleaning (normal $\mathrm{pH}(6.5)$ and alkaline $\mathrm{pH}$ (8)) in a plastic boxes at $28-30^{\circ} \mathrm{C}$ for $18 \mathrm{~h}$, using an incubator (Binder 78532 Tuttlingen, GERMANY). After steeping, cereals were drained and spread in plastic boxes, and left to germinate in the incubator (Binder 78532 Tuttlingen, GERMANY) at $28-30^{\circ} \mathrm{C}$. The germinating cereal were sprayed twice daily (morning and evening) by spraying clean water. The samples were dried using an oven at $45^{\circ} \mathrm{C}$ for $24 \mathrm{~h}$ in order to limit the loss of amylolytic enzymes. The degerming was done manually. The malting process diagram is described on Figure 1.

\section{Physico-chemical analyses}

The $\mathrm{pH}$ of the samples was measured with an electronic pHmeter (Model HI 8520; Hanna Instrument, Singapore) according to
Nout et al. (1989). The moisture content was determined by drying the sample at $105^{\circ} \mathrm{C} \pm$ $2^{\circ} \mathrm{C}$ for $12 \mathrm{~h}$ according to ISO 712 (2009). The diastatic power was determined according to the method of Bernfeld (1955) modified by Giamarchi (1992). It consists in making act, an enzymatic extract on a starch solution. The reducing sugars and reducing functions thus released are determinate by colorimetry (540 $\mathrm{nm}$ ) in the presence of 3-5 dinitrosalicylic acid. The $\alpha$-amylase activity was determined according to the method proposed by Giamarchi (1992), according to the same principle as that of the diastatic power, after extraction of the enzymes and inactivation of the $\beta$-amylase at $68^{\circ} \mathrm{C}$ for $15 \mathrm{~min}$. The $\beta$ amylase activity is deduced by the difference between the diastatic power and the alpha amylase activity. Amylase activity of germinated sorghum was measured using the method of Bernfeld (1955).

\section{Statistical analyses}

The data collected for the different parameters (three repetitions) were processed with the statistical software XLSTAT 7.5.2. When variables (humidity before and after steeping, 1000 grain weight, germination rate and rootlet rate) follow a normal law, analysis of variance (ANOVA) is perform. The average values were compared using Newman Keuls test $(\mathrm{p}=5 \%)$. For other variables (diastatic power, alpha and beta amylase activity, amylase activity, alpha to beta ratio, $\mathrm{pH}$, Dry matter) Kruskal-Wallis test is performed and Conover-Iman test is used to compare average value $(\mathrm{p}=5 \%)$. 


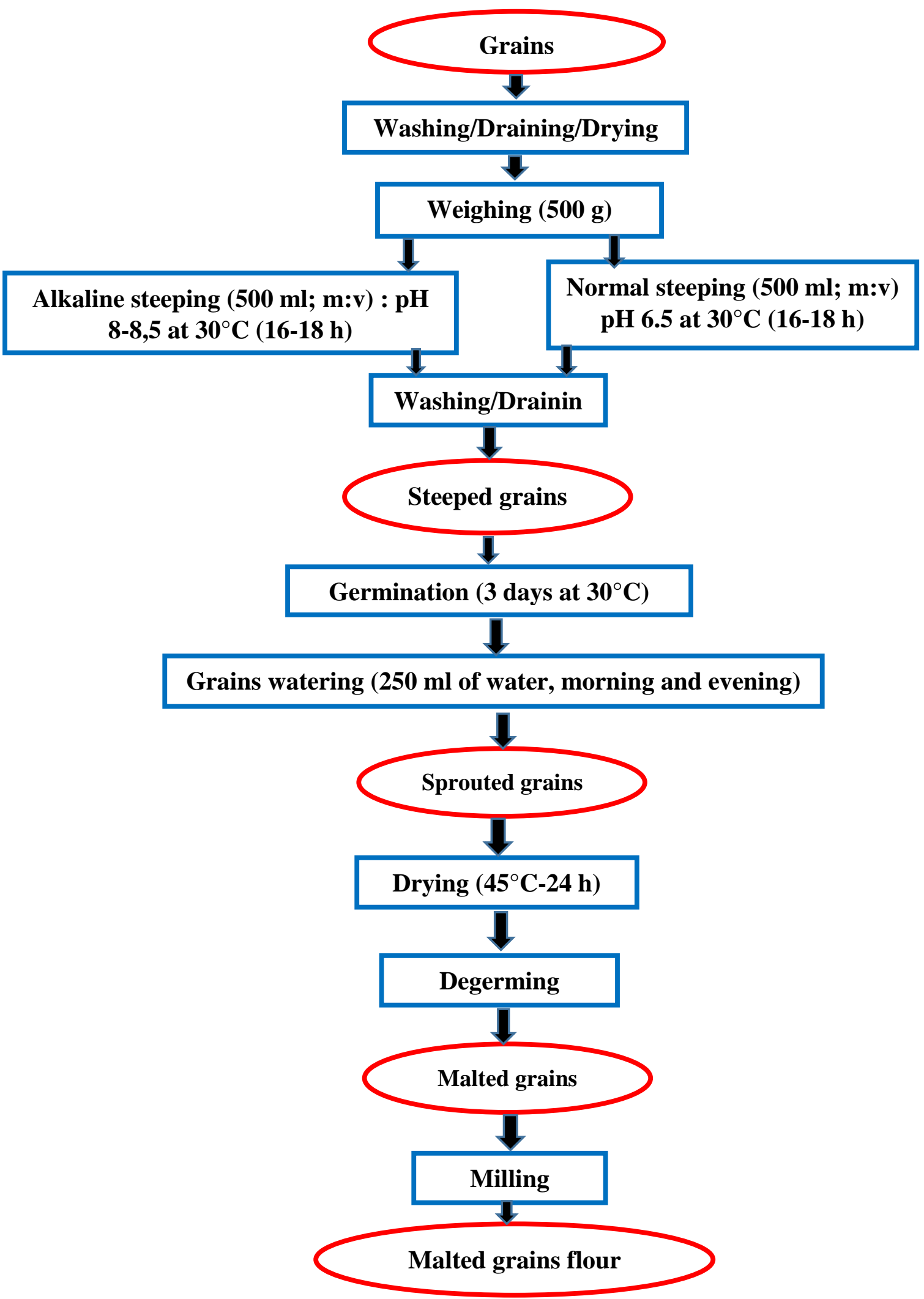

Figure 1: Malts production diagram. 


\section{RESULTS}

\section{Physico-chemical characteristics of non- malted sorghum and millet grains}

Physico-chemical characteristics of non-malted cereal are presented in Figure 2. The thousand grain weight of red sorghum, white sorghum and millet was respectively $27.63 \mathrm{~g} / 1000$ kernels; $24.34 \mathrm{~g} / 1000$ kernels and $9.86 \mathrm{~g} / 1000$ kernels. The moister content before and after non-alkaline steeping ( $\mathrm{pH}$ 6.5) varied from $10.70 \%$ to $39.82 \%$; from $11.76 \%$ to $32.30 \%$ and from $11.10 \%$ to $36.45 \%$ ) respectively for red sorghum, white sorghum and millet. As for the alkaline steeping ( $\mathrm{pH} \mathrm{8),}$ the moister content before and after steeping varied from $10.70 \%$ to $39.10 \%$; from $11.76 \%$ to $32.75 \%$ and from $11.10 \%$ to $37.58 \%$ respectively for red sorghum, white sorghum and millet. The germination rate was about $91 \%, 85.66 \%$ and $92.5 \%$ respectively for red sorghum, white sorghum and millet. The rate of rootlets resulting from losses during malting increased significantly from $2.52 \%$ (white sorghum malt) to $15.18 \%$ (red sorghum malt) (Figure 3). Millet malt had the highest loss rate $(9.42 \%)$ after $48 \mathrm{~h}$ malting (Figure 3). Statistical analyzes revealed a significant difference $(p<0.001)$ between the thousand grains weight of samples. Considering the germination rate, there is a significant difference between millet and white sorghum $(\mathrm{p}<0.001)$. A slight difference was observed between millet and red sorghum. For the moisture content after steeping, a significant difference was observed between non-alkaline steeping of red sorghum and the other $(\mathrm{p}<0.001)$. In the same way, a significant difference was observed between white sorghum (alkaline and non-alkaline steeping) and the other ones $(p<0.001)$. No significant difference $(p<0.001)$ was observed between red sorghum and millet alkaline soak.
Functional properties of sorghum and millet grains during malting process in control condition

The Functional properties of sorghum and millet grains during malting process in control condition are shown in Table 1. The values of diastatic power, alpha amylase and amylase activity increased significantly during the malting process $(p<0.001)$, as for the beta amylase content. The $\mathrm{pH}$ decreased significantly during the malting process $(\mathrm{p}<0.001)$, from 5.6 to 4.6 . The moisture content of the malted cereal after drying varies from $6.91 \%$ to $12.05 \%$. There was not enough difference in the various functional property between malt using alkaline steeping and normal steeping. No significant difference $(p<0.001)$ was observed for the moister content and dry matter of all the treatments. The highest values of diastatic power was obtained with millet malt (378.86 UPD and 336.45 UPD) respectively for normal and alkaline steeping. Diastatic power of sorghum malts varied from 79.14 UPD to 266.17 UPD. The lowest value for diastatic power was observed with white sorghum malt (79.14 UPD). The ratio alpha amylase/beta amylase ranged from 2.34 to 22.14 for all samples during the malting process.

A negative correlation emerged between the diastatic power and the $\mathrm{pH}(\mathrm{R}=-$ $0.88)$. When the $\mathrm{pH}$ decreased the diastatic power increased (Table 2). But, there was a strong correlation between diastatic power and amylase activity $(\mathrm{R}=0.95)$. The diastatic power was also more correlated with the activity of alpha amylase $(R=0.99)$ than that of beta amylase $(\mathrm{R}=0.6)$ (table 2$)$. Then when the alpha amylase content of malts increased, the diastatic power content also increased. In the same way, the alpha amylase activity of malts depend more in alpha amylase content than beta amylase content. 


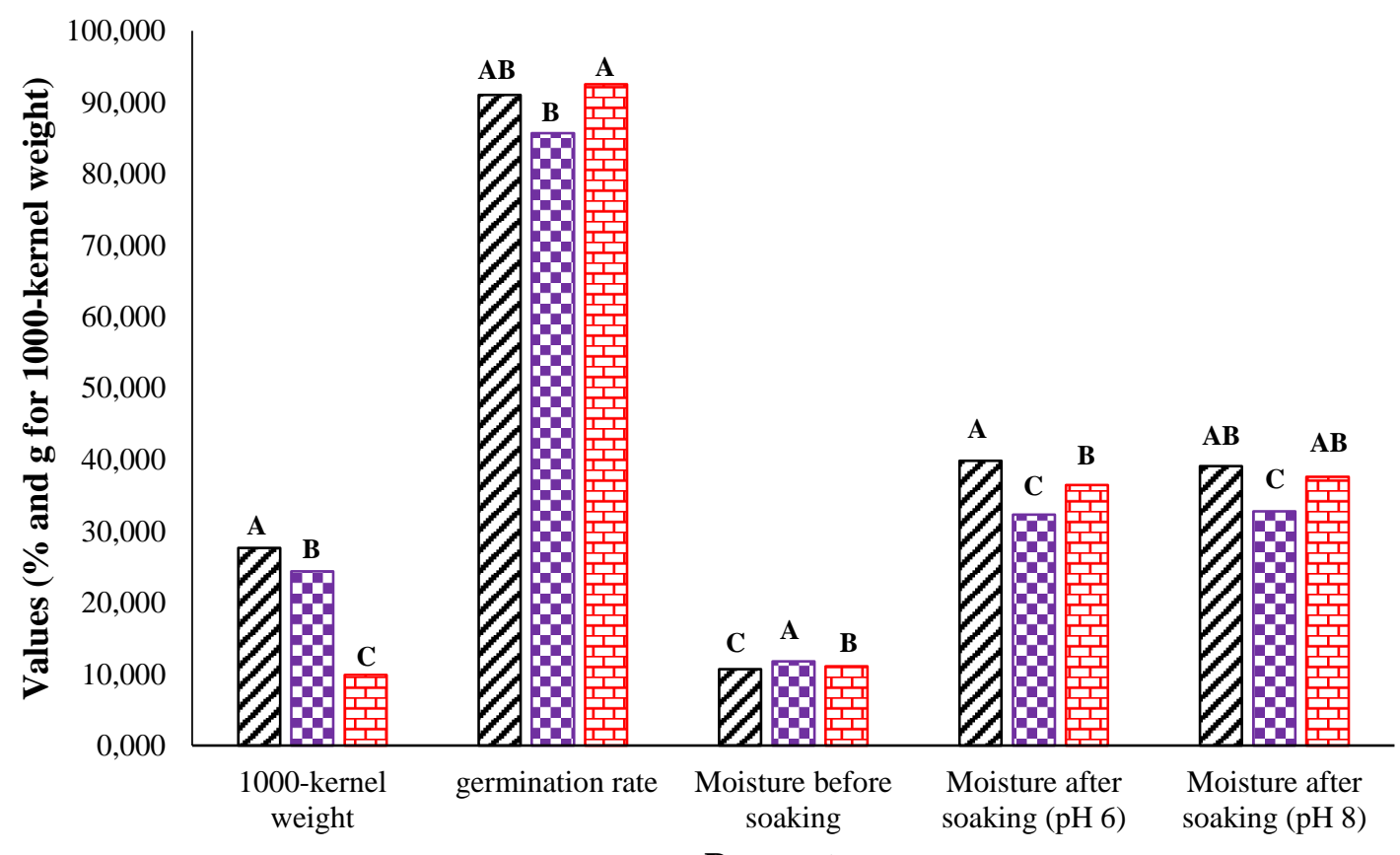

$\square \mathrm{SR} \square \mathrm{SB} \square \mathrm{PM}$

Figure 2: Grains characteristics before sprouting.

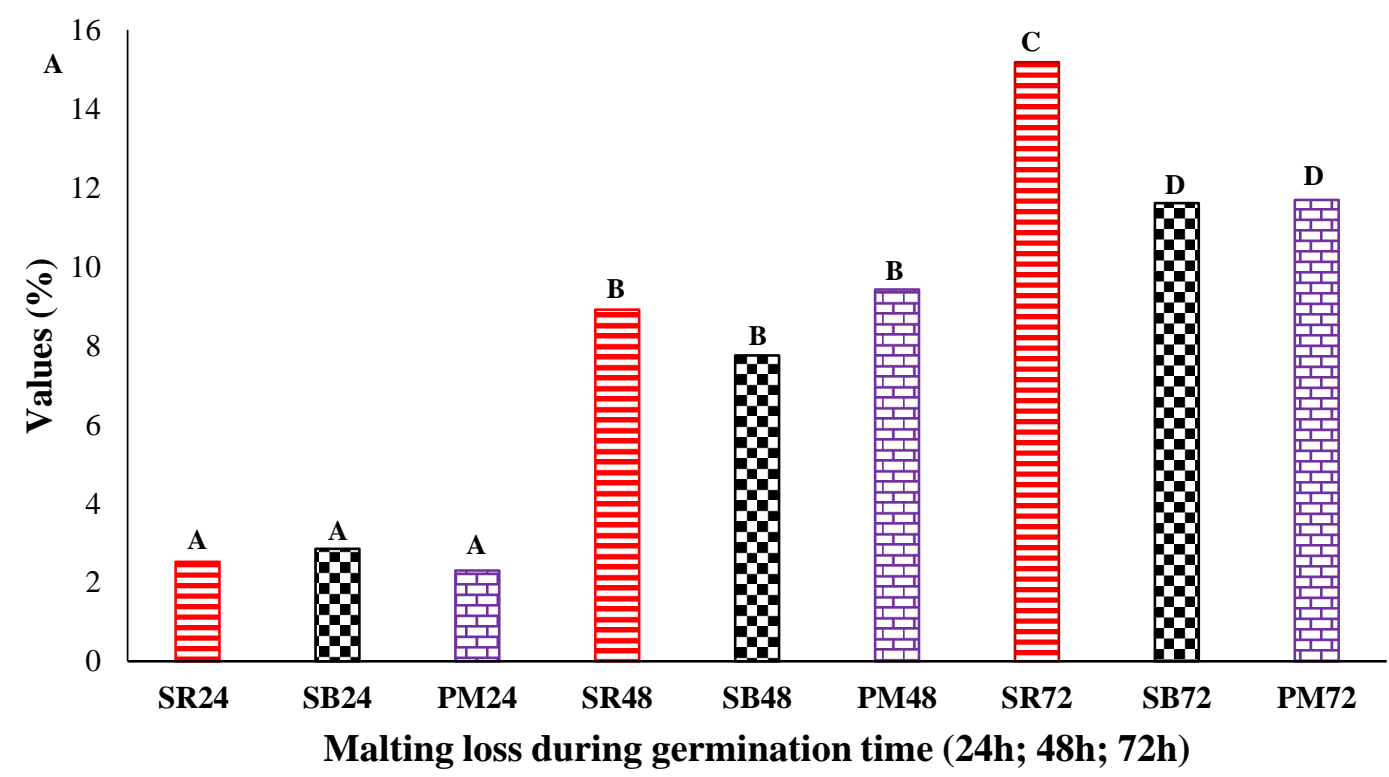

Figure 3: Malting losses during germination.

(SR: Red sorghum; SB: White sorghum; PM: pearl millet). 
Table 1: Functional properties characteristics of sorghum and millet malts.

\begin{tabular}{|c|c|c|c|c|c|c|c|c|}
\hline Samples & $\begin{array}{c}\text { Diastatic power } \\
\text { (UPD) }\end{array}$ & $\begin{array}{c}\text { Alpha_Amylases } \\
(\mathbf{U} / \mathbf{g})\end{array}$ & $\begin{array}{c}\text { Beta_Amylases } \\
(\mathrm{U} / \mathrm{g})\end{array}$ & $\begin{array}{c}\text { Alpha/Beta } \\
\text { Amylases }\end{array}$ & $\begin{array}{c}\text { Amylasic activity } \\
(\mathrm{U} / \mathrm{g})\end{array}$ & pH & $\begin{array}{c}\text { Moister } \\
\text { content }(\%)\end{array}$ & $\begin{array}{c}\text { Dry matter } \\
(\%)\end{array}$ \\
\hline SRn24 & $90.65 \pm 17.59^{\mathrm{ab}}$ & $62.95 \pm 11.85^{\mathrm{ab}}$ & $27.70 \pm 7.81^{\operatorname{defg}}$ & $2.34 \pm 0.46^{\mathrm{a}}$ & $75.29 \pm 6.67^{\mathrm{ab}}$ & $5.6 \pm 0.0^{\mathrm{ef}}$ & $6.91 \pm 0.60^{\mathrm{a}}$ & $93.09 \pm 0.58^{a}$ \\
\hline SBn24 & $98.91 \pm 1.78^{\mathrm{abc}}$ & $74.80 \pm 2.8^{\mathrm{abc}}$ & $24.11 \pm 2.92^{\text {bcde }}$ & $3.14 \pm 0.51^{\mathrm{ab}}$ & $85.47 \pm 3.80^{\mathrm{abc}}$ & $5.6 \pm 0.0^{\mathrm{ef}}$ & $7.53 \pm 0.13^{\mathrm{a}}$ & $92.47 \pm 0.13^{\mathrm{a}}$ \\
\hline $\mathrm{SBb} 24$ & $92.78 \pm 2.90^{\mathrm{ab}}$ & $69.93 \pm 1.12^{\mathrm{abc}}$ & $22.84 \pm 1.79^{\mathrm{abcde}}$ & $3.07 \pm 0.19^{\mathrm{ab}}$ & $71.98 \pm 1.68^{\mathrm{a}}$ & $5.6 \pm 0.0^{\mathrm{def}}$ & $7.47 \pm 0.5^{\mathrm{a}}$ & $92.52 \pm 0.47^{\mathrm{a}}$ \\
\hline $\mathrm{PMn} 24$ & $133.77 \pm 12.58^{\mathrm{de}}$ & $108.93 \pm 9.63^{\text {cde }}$ & $24.84 \pm 3.56^{\text {cdef }}$ & $4.41 \pm 0.40 \mathrm{~b}^{\mathrm{cd}}$ & $96.87 \pm 2.15^{\mathrm{cde}}$ & $5.7 \pm 0.0^{\mathrm{f}}$ & $7.51 \pm 0.3^{\mathrm{a}}$ & $92.48 \pm 0.23^{\mathrm{a}}$ \\
\hline \multicolumn{9}{|c|}{$48 \mathrm{~h}$ of malting } \\
\hline SRn48 & $141.51 \pm 8.81^{\mathrm{def}}$ & $120.67 \pm 9.94^{\mathrm{de}}$ & $20.85 \pm 1.21^{\text {abcde }}$ & $5.82 \pm 0.79^{\text {defg }}$ & $142.65 \pm 5.26^{\mathrm{fg}}$ & $5.3 \pm 0.1^{\mathrm{ab}}$ & $7.82 \pm 0.52^{\mathrm{a}}$ & $92.18 \pm 0.52^{\mathrm{a}}$ \\
\hline $\mathrm{SRb} 48$ & $149.99 \pm 2.41^{\mathrm{efg}}$ & $127.82 \pm 2.58^{\mathrm{efg}}$ & $22.17 \pm 0.20^{\text {abcde }}$ & $5.76 \pm 0.16^{\operatorname{defg}}$ & $131.92 \pm 3.58^{\text {ef }}$ & $5.4 \pm 0.0^{\mathrm{bcd}}$ & $7.16 \pm 0.55^{\mathrm{a}}$ & $92.84 \pm 0.55^{\mathrm{a}}$ \\
\hline $\mathrm{SBn} 48$ & $153.94 \pm 10.60^{\text {efg }}$ & $126.46 \pm 8.21^{\mathrm{def}}$ & $27.48 \pm 4.71^{\operatorname{defg}}$ & $4.68 \pm 0.75^{\mathrm{bcd}}$ & $129.43 \pm 4.43^{\mathrm{def}}$ & $5.4 \pm 0.0^{\text {cde }}$ & $8.39 \pm 1.81^{\mathrm{a}}$ & $91.61 \pm 1.81^{\mathrm{a}}$ \\
\hline $\mathrm{SBb} 48$ & $134.27 \pm 5.60^{\text {cde }}$ & $128.41 \pm 5.78^{\mathrm{efg}}$ & $5.86 \pm 0.73^{\mathrm{a}}$ & $22.14 \pm 3.10^{\mathrm{i}}$ & $150.44 \pm 8.99^{\mathrm{gh}}$ & $5.4 \pm 0.0^{\text {bcde }}$ & $7.94 \pm 0.60^{\mathrm{a}}$ & $92.06 \pm 0.60^{\mathrm{a}}$ \\
\hline PMn48 & $239.85 \pm 25.63^{\mathrm{hi}}$ & $201.91 \pm 25.71^{\text {ghi }}$ & $37.94 \pm 2.03^{\mathrm{fg}}$ & $5.33 \pm 0.75^{\text {cde }}$ & $149.52 \pm 2.38^{\mathrm{g}}$ & $5.4 \pm 0.1^{\mathrm{bcd}}$ & $8.39 \pm 2.04^{\mathrm{a}}$ & $91.61 \pm 2.04^{\mathrm{a}}$ \\
\hline SBn72 & $266.17 \pm 12.94^{\mathrm{ijk}}$ & $237.33 \pm 17.10^{\mathrm{ijk}}$ & $28.84 \pm 4.31^{\mathrm{efg}}$ & $8.40 \pm 1.77^{\mathrm{ghi}}$ & $198.95 \pm 1.65^{\mathrm{hi}}$ & $5.1 \pm 0.2^{\mathrm{ab}}$ & $9.86 \pm 3.66^{\mathrm{a}}$ & $90.14 \pm 3.66^{a}$ \\
\hline $\mathrm{SBb} 72$ & $265.31 \pm 9.81^{\mathrm{ijk}}$ & $224.81 \pm 6.90^{\mathrm{hijk}}$ & $40.50 \pm 4.10^{\mathrm{g}}$ & $5.58 \pm 0.49^{\text {cdef }}$ & $199.19 \pm 1.23^{\mathrm{hi}}$ & $4.8 \pm 0.2^{\mathrm{a}}$ & $8.54 \pm 1.09^{\mathrm{a}}$ & $91.46 \pm 1.09^{\mathrm{a}}$ \\
\hline PMn72 & $378.86 \pm 10.64^{k}$ & $338.68 \pm 7.71^{\mathrm{k}}$ & $40.18 \pm 5.21^{\mathrm{g}}$ & $8.52 \pm 1.09^{\mathrm{fghi}}$ & $302.27 \pm 15.52^{\mathrm{j}}$ & $4.6 \pm 0.0^{\mathrm{a}}$ & $12.05 \pm 2.94^{\mathrm{a}}$ & $87.94 \pm 2.94^{\mathrm{a}}$ \\
\hline PMb72 & $336.45 \pm 6.44^{\mathrm{j} k}$ & $298.98 \pm 4.11^{\mathrm{jk}}$ & $37.47 \pm 2.38^{\mathrm{fg}}$ & $7.99 \pm 0.41^{\mathrm{fgh}}$ & $314.43 \pm 5.52^{\mathrm{j}}$ & $4.6 \pm 0.4^{\mathrm{a}}$ & $8.89 \pm 1.68^{\mathrm{a}}$ & $91.11 \pm 1.68^{a}$ \\
\hline
\end{tabular}

SRn : Red sorghum normal steeping; SRb : Red sorghum alkaline steeping ; SBn : White sorghum normal steeping ; SBb : White sorghum alkaline steeping; PMn : Pearl millet normal steeping ; PMb : Pearl millet alkaline steeping. 24; 48; 72: Germination time (in hours). 
Table 2: Correlation matrix of functional properties parameters.

\begin{tabular}{|c|c|c|c|c|c|c|c|c|}
\hline & Diastatic power & Alpha_Amylases & Beta_Amylases & $\begin{array}{l}\text { Alpha/Beta } \\
\text { amylases }\end{array}$ & $\begin{array}{c}\text { Amylasic } \\
\text { activity }\end{array}$ & pH & $\begin{array}{l}\text { Water } \\
\text { content }\end{array}$ & Dry matter \\
\hline Diastatic power & 1 & 0.995 & 0.600 & 0.243 & 0.950 & -0.888 & 0.593 & -0.593 \\
\hline Alpha_Amylases & 0.995 & 1 & 0.520 & 0.323 & 0.958 & -0.888 & 0.595 & -0.595 \\
\hline Beta_Amylases & 0.600 & 0.520 & 1 & -0.526 & 0.463 & -0.499 & 0.315 & -0.315 \\
\hline Alpha/Beta amylases & 0.243 & 0.323 & -0.526 & 1 & 0.343 & -0.251 & 0.203 & -0.203 \\
\hline Amylasic activity & 0.950 & 0.958 & 0.463 & 0.343 & 1 & -0.916 & 0.584 & -0.584 \\
\hline pH & -0.888 & -0.888 & -0.499 & -0.251 & -0.916 & 1 & -0.491 & 0.491 \\
\hline Water content & 0.593 & 0.595 & 0.315 & 0.203 & 0.584 & -0.491 & 1 & -1.000 \\
\hline Dry matter & -0.593 & -0.595 & -0.315 & -0.203 & -0.584 & 0.491 & -1.000 & 1 \\
\hline
\end{tabular}




\section{DISCUSSION}

The moisture content of sorghum and millet grains after steeping increased significantly $(\mathrm{p}<0.001)$ and this is evidence of good grain steeping practice. Steeping is a determining factor for the success of malting process. It provides the necessary quantities of water and oxygen for germination and contribute to it sanitary quality by removing light grains and some impurities (Kpoda, 2008). A minimum water content of $35 \%$ at the end of steeping allows good germination (Mathoto, 2007). This moister content promotes the proliferation of microorganisms (Mathoto, 2007) and determines the efficiency of germination. The germination rate determined in this study were higher than recommended one $(90 \%)$ for the production of high malt quality (Mathoto, 2007; Okpalanma et al., 2020) except for the white sorghum. The thousand grain weights of the sorghum were lower than those found by Okpalanma et al. (2020) for red sorghum, while the thousand grain weight of millet was higher than that found by Okpalanma et al. (2020). The result showed that the malting loss of the grains increased with increase in the duration of germination. Significant increases in malting loss were recorded between 1-3 days of germination. These results corroborate those of Okpalanma et al. (2020), who also found a significant increase in malting loss during 2-4 days germination. The malting losses observed in this study are adequate because an average of $10-15 \%$ respirations / metabolic loss is expected in well-malted sorghum with good diastatic power (Okpalanma et al., 2020). The diastatic power of the produced malts in this study evolved significantly during the malting process as a function of alpha amylase and amylase activities and weakly with that of $\beta$ amylase. These results corroborate those of Kayodé et al. (2011) and Trust et al. (2014) who also found a positive evolution between the diastatic power of sorghum and the alpha amylase and beta amylase activities. The diastatic power of millet malt was greater than that of sorghum malt. This could be explained by the structural composition of sorghum grain which is rich in tannins and would not promote the malting process by reducing the enzymatic digestibility. Some studies also showed that these phenolic compounds also aim to protect the grains against fungus attack, insects and birds, reducing the enzymatic digestion as well as the proteins, starch and others polysaccharides, which are an obvious agronomic advantage, (Tawaba et al., 2013; Tapsoba et al., 2017). In addition, millet grains present a higher germination power than the sorghum one. The diastatic power of sorghum malts found in this study (266.17 UPD) was slightly higher than that found by kayodé et al. (2011) on sorghum malts (229.8 UPD). The $\alpha / \beta$ amylase ratio is high for the various malt. The $\alpha$-amylase contents are then higher than $\beta$ amylase. The activities of $\alpha$-amylase enzymes have been shown in other studies to be superior to $\beta$-amylase (Dziedzoave et al., 2010). These results corroborate those of $\mathrm{Ba}$ (2013) who report predominant $\alpha$-amylase contents in the sorghum malting process. The diastatic power found in this study were higher than those found by Kayodé et al. (2011). These high diastatic power contents could be explained in part by the good steeping rates and the drying temperature of $45^{\circ} \mathrm{C}$. All this makes it possible to limit the losses of amylotic enzymes (Kayodé et al., 2011). The $\mathrm{pH}$ value is close to the optimal one for $\alpha$-amylase and $\beta$-amylase (5.5-6) activity of sorghum malt found by Nour and Yagoub (2010) and $\mathrm{Ba}$ (2013). The $\mathrm{pH}$ is negatively correlated with the diastatic power, amylase and alpha amylase activity. These results corroborate those found by Kayodé et al. (2011) who also found $\mathrm{pH}$ values that were negatively correlated with the diastatic power, alpha and beta amylase activity of sorghum malt. The $\mathrm{pH}$ value is similar to those found by Pare (2019) during the malting of sorghum for the production of dolo. This drop in $\mathrm{pH}$ could be due to the acidity produced by lactic acid bacteria during malting. It allows the $\mathrm{pH}$ to be lowered and increase the rate of enzymatic activities (Maoura et al., 2006). The moister contents of the malt samples varied from 7 to $9 \%$. These results are lower than those found by Pare (2019) but comply with the conservation standards ( $<15 \% \mathrm{~m} / \mathrm{m}$ maximum) of Codex STAN. 173-1989 (Pare, 2019). These results 
show that the malt samples can be stored well in a dry place for future uses.

The different values of the functional properties of the malts produced in this study illustrate the quality of the different malts in terms of their use in industry. These malts could therefore be used for the production of infant porridge in order to increase the energy density of porridge. They could also be used in bread making to replace commercial enzymes.

\section{Conclusion}

The diastatic power of malts correlate with the alpha amylase and amylase activity. No significant difference $(\mathrm{p}<0.001)$ was observed in the diastatic power of malts soaked at normal $\mathrm{pH}$ and the diastatic power of cereal malts soaked at alkaline $\mathrm{pH}$. Millet malt had the highest diastatic power compared to sorghum malts. The diastatic power was negatively correlated with the $\mathrm{pH}$. Overall, the different types of malts exhibited satisfactory diastatic power and functional properties in accordance with standards for cereal malt production. These malts could therefore be used for the production of infant porridge in order to increase the energy density of porridge and also used in bread making to replace commercial enzymes often not appreciated by consumers.

\section{COMPETING INTERESTS}

The authors declare that they have no competing interests.

\section{AUTHORS' CONTRIBUTIONS}

FWBT, TJNY, EWWB and AO contributed to sample analysis and to obtain results at laboratory. FWBT, SS, HC, MHD and HS-L contributed to the writing of this article.

\section{ACKNOWLEDGMENTS}

Authors would like to thank everyone who contributed to this study.

\section{REFERENCES}

Ba K. 2013. Contribution à l'étude des amylases du sorgho et leurs utilisations dans la transformation des produits amylacés. Thèse de Doctorat, Gembloux
Agro-Biotech, Université de Liège, Belgique, $147 \mathrm{p}$.

Bellaio S, Kappeler S, Rosenfeld EZ, Jacobs M. 2014. Partially germinated ingredients for naturally healthy and tasty products. Cereal Foods World, 59(5): 231-233.

Bernfeld P. 1955. Enzymes of carbohydrate metabolism: amylases alpha and beta. In Methods In Enzymology, Colowish SP, Kaplain NO (Eds). New York Academic Press: New York; 146-158.

Cardoso LM, Montini AT, Pinheiro SS, Silva LL, Menezes CB, Carvalho CWP. 2015. Tocochromanols and carotenoids in sorghum (Sorghum bicolor L.): Diversity and stability to the heat treatment. Food Chem., 172: 900-908. DOI: 10.1016/j.foodchem.2014.09.117

Li C, Ho S-G, Lee D-H, Baik H-W, Chung HJ. 2017. Effect of germination on the structures and physicochemical properties of starches from brown rice, oat, sorghum, and millet. Int. J. Biol. Macromol., 105 (1): $\quad 931-939 . \quad$ DOI: 10.1016/j.ijbiomac.2017.07.123

Dicko MH, Gruppen H, Traoré AS, Voragen AGJ, van Berkel WJH. 2006. Sorghum grain as human food in Africa: relevance of content of starch and amylase activities. African Journal of Biotechnology 5: 384395.

Dziedzoave NT, Graffham AJ, Westby A, Komlaga G. 2010. Comparative assessment of amylolytic and cellulolytic enzymes activity of malts prepared from tropical cereals. Food Control, 21: 13491353.

Kayodé APP, Ahouanse I.S, Kotchoni SO, Hounhouigan JD. 2011. Optimisation du procédé traditionnel de maltage du sorgho pour la production de boissons fermentées. Int. J. Biol. Chem. Sci., 5(4): 1552-1561.

DOI: http://dx.doi.org/10.4314/ijbcs.v5i4.20

Maoura N, Mbaiguinam M, Gaillardin C, Pourquie J. 2006. Suivi technique, analytique et microbiologique $\mathrm{du}$ « bili bili » bière traditionnelle tchadienne. Afrique Science, 02(1): $69-82$. 
Mathoto LL. 2007. Control of microbial proliferation on sorghum during malting. $\mathrm{PhD}$ Thesis, Food Sciences, University of Pretoria, Pretoria, $137 \quad \mathrm{p}$ http://hdl.handle.net/2263/25338

Mbofung CM, Fombang EN. 2003. Improving the digestibility and availability of nutrients from sorghum flour through improved malting techniques. $2^{\text {nd }}$ International workshop: Food-based approaches for a healthy nutrition, Ouagadougou, 23- 28/11/2003, 489-502.

Nour MEME, Yagoub SO. 2010. Partial purification and characterization of $\alpha$ and $\beta$-amylase isolated from Sorghum bicolor cv. (Feterita) malt. J. Appl. Sci., 10: 13141319. DOI: $10.3923 /$ jas.2010.1314.1319

Nout MJR, Rombouts FM, Havelaar A. 1989. Effect of accelerated natural lactic fermentation of infant food ingredients on some pathogenic microorganisms. Int. J. Food Microbiol., 8: 351-361. DOI: 10.1016/0168-1605(89)90006-8

Oi Y, Kitabatake N. 2003. Chemical composition of an East African traditional beverage, Togwa. Journal of Agricultural and Food Chemistry, 51: 7024-7028. DOI: https://doi.org/10.1021/jf0203343

Okpalanma EF. 2020. Production of Maltbased Sugar Syrup from Enzymatic Hydrolysis of Malted Sorghum and Millet Grains. Asian Food Science Journal, 14(4): 1-17. DOI: 10.9734/AFSJ/2020/v14i430134

Pare A. 2019. Technologies et caractéristiques physico-chimiques du dolo produit à Ouagadougou. Mémoire de Master en biotechnologie, Option Microbiologie et Technologie Alimentaire (MTA), Université de Ouagadougou, 83 p.

Richter K, Christiansen K, Guo G. 2014. Wheat sprouting enhances bread baking performance. Cereal Foods World, 59(5): 231-233. DOI: 10.1094/CFW-59-5-0231

Tapsoba FW, Sawadogo-Lingani H, Kabore D, Compaore-Sereme D, Dicko MH. 2017. Effect of the fermentation on the microbial population occurring during the processing of zoom-koom, a traditional beverage in Burkina Faso. Afr. $J$. Microbiol. Res., 11(26):1075-1085.

Tawaba JCB, Ba K, Destain J, Malumba P, Béra F, Thonart P. 2013. Vers une intégration du sorgho comme matière première pour la brasserie moderne (synthèse bibliographique). Biotechnol. Agron. Soc. Environ., 17(4): 622-633.

Tou EH, Mouquet C, Guyot JP, Traore AS, Trèche $S$. 2003. Essai de modification du procédé traditionnel de fabrication des bouillies de mil fermenté ben-saalga en vue d'augmenter leur densité énergétique. $2^{\text {ème Atelier international: Voies }}$ alimentaires d'amélioration des situations nutritionnelles, Ouagadougou, 23-28 / 11 / 2003, 517-524.

Towo EE, Svanberg U, Ndossi GD. 2003. Effect of grain pre-treatment on different extractable phenolic groups in cereals and legumes commonly consumed in Tanzania. Journal of the Science of Food and Agriculture, 83: 980-986. DOI: https://doi.org/10.1002/jsfa.1435

Traoré T, Mouquet C, Icard-Vernière C, Traoré AS, Trèche S. 2004. Changes in nutrient composition, phytate and cyanide contents and alpha-amylase activity during cereal malting in small production units in Ouagadougou (Burkina Faso). Food Chemistry, 88: 105-114.

Trust b, Lloyd WR, Ralph DW. 2014. Malting Characteristics of Sorghum Cultivars. Cereal Chem., 72(6): 533-538. 